\title{
Teaching and Learning: Essential Components of the Nurse Executive Role
}

\author{
Susan K. Pfoutz, Lillian M. Simms and Sylvia A. Price
}

Administrative leadership inspires, encourages innovation, assists staff to grow and promotes and facilitates excellent nursing. Although one might argue that these activities are administrative, data collected in research at the University of Michigan suggest that they have a strong educational tone. Analysis of the data resulting from in-depth interviews in practice and education indicates that the role of the executive is on a trajectory of intrapersonal integration of the professional components of practice. The education component is vital to integrating the role and is the linchpin in linking the components of professional practice.

$\mathrm{T}$ he role of the nurse executive is a dynamic one requiring a high degree of leadership skill and managerial competence intricately linked with clinical nursing knowledge and research. This phase of a continuing project expands on previously reported findings and concentrates on the education-related responsibilities of the nurse executive. The education capabilities are vital to integrating the role; education is the linchpin in linking the components of professional practice.

\section{The Executive as a Teacher/Learner}

The role of nurse executives as teachers has been largely unrecognized. In their efforts to stay away from educational roles many executives may not recognize that extensive education occurs in noncredit, informal learning environments. Changing behavior in organizations is a major responsibility of the nurse executive and one that involves teaching/learning expertise.

Executive leadership inspires, encourages innovation, assists staff in the self-actualizing process and promotes and facilitates excellent nursing. In previously reported research, nursing administrators were found to be involved in personal and other-directed leadership activities with the majority of executives considering themselves to be mentors for others (Simms, Price, \& Pfoutz, 1985). Other leadership activities identified in the previous report included activities as (a) an image setter, (b) spokesperson for nursing, (c) change agent, (d) people developer, (e) trouble-shooter and (f) creator of a professional practice environment. These leadership activities are in essence teaching-learning activities.

The study supported Drucker's (1980) contention that managers do many things that are not managing and spend most of their time doing things other than planning, organizing, directing and evaluating.

In addition to leadership skills, the earlier study of nurse executives reaffirmed the high degree of managerial acumen required of these clinical leaders. The nurse executive was found to function as a planner, image setter and resource allocator who facilitates rather than performs direct services. The study further supported Poulin's (1984) findings that a new nurse executive role is emerging that requires clinical nursing knowledge and research as well as leadership and managerial skill.

Previous reports of this research focused on administrators in acute, long-term and home care settings. Realizing that a major component of the administrative function included education-related activities, the project was expanded to include interviews with nurse executives in colleges of nursing. The setting for executive practice was reconceptualized to include education as well as service settings. The work of Mintzberg (1973), Price (1984), Poulin (1984) and Stevens (1981) were used in developing the original interview schedule. During the expanded phase of the project, the interview schedule was further refined for use in the education setting.

This research addressed the following questions:

1. What are the characteristics of nurse executives in practice and education?

2. What are the education-related responsibilities of these executives?

3. How do selected functions differ between educational and practice settings?

4. What are the trends in educational responsibilities?

\section{Methods}

This research conceptualizes nursing administration as a professional practice discipline that articulates and integrates the essential components of clinical practice, research, education and administration. The nurse executive is conceived to

SUSAN K. PFOUTZ, R.N., M.S.N., Rho, is a doctoral candidate and Research Associate at The University of Michigan School of Nursing; LILLIAN M. SIMMS, R.N., Ph.D., Rho, is Associate Professor of Nursing Administration, The University of Michigan School of Nursing and Project Director, Role of the Nurse Executive Project; SYLVIA A. PRICE, R.N., Ph.D, Rho, is Associate Professor of Nursing Administration at the College of Nursing, University of Tennessee and was a Research Associate for this Project. The research on which this article is based was conducted at The University of Michigan and was supported by a Division of Nursing Research Emphasis/Doctoral Program Grant and an NIH Biomedical Research Support Crant. Correspondence to Prof. Simms, The University of Michigan School of Nursing, Room 2174, 400 North Ingalls, Ann Arbor, Ml 48109.

Accepted for publication May 19, 1987. 
be the top nurse administrator in any health-related service or educational enterprise. The constant comparative method of Glaser and Strauss (1967) was used as an inductive approach to develop grounded theory. Data sources included a) literature review, b) taped interviews, c) biographic forms, d) monthly calendars and e) organizational charts. The data were categorized according to conceptual categories identified in the previous research, and related properties and interrelationships were studied (Simms, 1981).

\section{Sample}

A convenience sample of 36 nurse executives was selected from 10 acute care institutions, 10 homecare agencies, 10 long-term care facilities and 6 educational facilities. Previously collected data from service settings were pooled with data from executives in the educational settings-research universities and two-year and four-year colleges. Registered nurses serving in executive roles were selected for interviews. These settings were selected because they are considered to be representative of both education and service settings, locally and nationally.

\section{Data Analysis}

Following collection of the data, tapes were transcribed and data were converted to responses on the interview forms. The responses were then coded and converted to cards for each identified category and question. For this phase of the research, coded data were analyzed according to the education-related research questions.

The data results were described according to characteristics of the subjects, perceived educational functions, variation between education and service settings and trends in education responsibilities.

\section{Characteristics}

The 36 executives in this study were predominantly female and between the ages of 30 and 65 . The majority of the executives in long-term care, home care and educational settings were in their $40 \mathrm{~s}$ and $50 \mathrm{~s}$, while the majority in acute care were in their 30s. Most of the executives in education were doctorally prepared and married; the majority of executives in practice were single. There was a marked difference between the levels of preparation of the long-term care executives and other executives : 78 percent were prepared at the undergraduate level (predominantly Associate degree and diploma), and all of the subjects in acute care, home care and educational settings were prepared at the graduate level (see Table 1).

Although several of the executives in service settings had adjunct faculty appointments, only the educational executives cited joint faculty and administrative titles. One dean and professor was also the director of Nursing Services; one associate hospital administrator was also an assistant dean. Without exception, all titles reflected the single top nursing leader within the setting.

\section{Perceived Educational Activities}

All perceived educational activities were identified and clustered according to previously identified and emerging categories: a) personal learning, b) direct teaching, c) institutional and d) external activities. In this manner, several activities not previously noted in the literature became evident including:

$$
\begin{gathered}
\text { Homework/self-study } \\
\text { Credentialing activities }
\end{gathered}
$$

\author{
Data analysis \\ Student supervision \\ Scholarly writing \\ Consultation \\ Peer collaboration \\ Lecture/seminar/paper \\ presentation
}

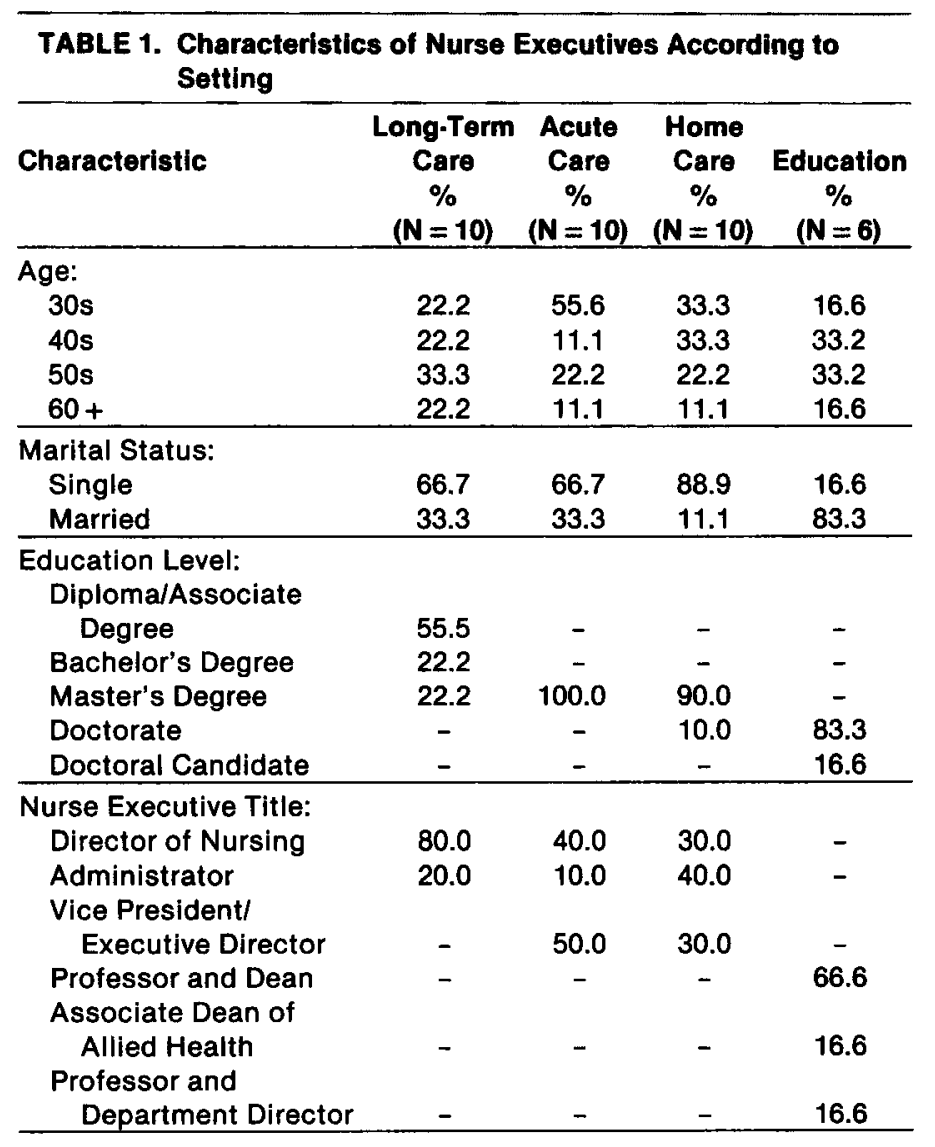

Note: Percentages adjusted to 100 when data missing.

Table 2 summarizes the educational activities identified by participants. Of particular note are the homework activities described by corporate executives. The personal learning activities were described as being absolutely essential to maintaining competence and included regular self-learning experiences about such topics as computer use, financial/data management, negotiation/bargaining and reimbursement policies. Daily preparation for meetings and speaking engagements was considered mandatory.

It is particularly noteworthy that most subjects described individual or collaborative activities for self-development rather than formal education, which depends on a higher authority. Such networking activities may have been part of a larger organization or developed by individuals within a given geographical area.

Direct educational activities included teaching inside as well as outside of the organization. As one would suspect, the education administrators were more likely to be involved in formal classroom teaching. Interestingly, long-term care executives were also heavily involved in direct teaching activities and as a group they were the least prepared for this activity. In addition to teaching activities, executives in all settings were involved in the planning and facilitation of educational programs within their organization. 
TABLE 2. Educational Activities of Nurse Executives

\begin{tabular}{|c|c|}
\hline Personal Learning Activities & External Activities of Influence \\
\hline $\begin{array}{l}\text { Homework/self-study } \\
\text { Networking for mutual growth } \\
\text { and development } \\
\text { Formal education } \\
\text { Continuing education } \\
\text { (conferences, workshops) } \\
\text { Reading } \\
\text { Scholarly efforts/publishing } \\
\text { Report writing }\end{array}$ & $\begin{array}{l}\text { Collaborative activities between } \\
\text { service and education } \\
\text { Presentations to community } \\
\text { groups } \\
\text { Work with health occupation } \\
\text { students } \\
\text { New program planning (hospice, } \\
\text { geriatrics, nursing models) } \\
\text { Service on review boards and } \\
\text { advisory committees } \\
\text { Organizational memberships } \\
\text { Health teaching in community } \\
\text { Patient/client education programs } \\
\text { Participation in policy setting at } \\
\text { national, state and local levels } \\
\text { Networking for organizational } \\
\text { responsibilities }\end{array}$ \\
\hline
\end{tabular}

Indirect Teaching

Opportunities

Establishing standards for credentialing

Preparation for accreditation

Grant writing

Committee meetings

Plan/support educational services

Facilitate educational opportunities for subordinates

Staff/faculty development

Program evaluation

Deliver educational services

Orientation of new personnel

to organizational and

nursing goals

Policy development for clinical practice

The corporate executives had a broad scope of educational influence with lectures, presentations and numerous activities beyond their own organization. These executives belonged to nursing and nonnursing organizations including hospital administration, medical and public health organizations, indicating a high level of involvement and opportunity for an extensive sphere of influence. In addition to the traditional nursing organizations, the corporate executives belonged to:

American Public Health Association

The Association for the Advancement of Science American Hospital Association

State Board of Nursing Home Administrators Institute of Medicine

American Society for Health, Manpower and Training.

\section{Importance of Educational Activities}

Another way to examine educational activity is to look for indicators of its relative importance to nurse executives. During the interviews, questions were asked about the central focus of the subjects' role as well as the most important and most satisfying aspects of that role. In addition, the subjects were asked to identify barriers and inhibitors to various aspects of their work.

The subjects were able to identify multiple, important aspects of their roles. Quality of care was the most frequently cited issue of importance in all practice settings. Some execu- tives in all practice settings cited staff recruitment and development as important aspects of their role in providing quality care or education.

Another approach was to inquire what inhibits or facilitates executives in reaching their goals. In many cases the desired characteristic was identified as a facilitator, while its absence was identified as an inhibitor. The need for qualified staff was recognized consistently as being important to achieving goals.

The executives were also asked what was the most satisfying aspect of their role: 20 percent of the long-term care executives, 70 percent of the acute care executives, 40 percent of the home care executives and 33 percent of the educators responded by citing staff growth and staff relationships. Recognizing that more than 70 percent of long-term executives were involved in staff development, the satisfaction rate of only 20 percent is of concern.

Overall, these findings suggest that the majority of nurse executives do not link staff development with maintaining a well-qualified staff. Only in acute care was staff growth recognized as the most satisfying aspect of the role by the majority of the respondents. The question arises as to why nurse executives in education did not view this aspect more favorably. Rapidly changing health care environments should be mandating a high level of growth and development among faculty members in education as well as in practice settings. The presence of well-qualified staff members who are able to meet the changing needs of their organizations is critical in all settings.

\section{Trends in Education Responsibilities}

We believe that we have only scratched the surface of education-related activities. Although formal educational programs were for the most part perceived as inservice education, there was a growing awareness of new program development requiring proposal writing and staff education. As shown in Table 3, the majority of executives perceived themselves as being mentors or preceptors, suggesting that the role of creator of learning environment is not yet well developed. In addition, the executives saw themselves as learners with an emerging awareness of personal growth and development. To further personal development, means beyond formal education programs and continuing education were being used. These reflected a more collaborative and peer-oriented focus. Executives in all settings have major responsibility for setting standards for credentialing of nurses. All executives share the responsibility for creating environments that prepare and retain professional competence and expertise through policy setting.

\begin{tabular}{|c|c|c|c|c|}
\hline Activity & $\begin{array}{c}\text { Long-Term } \\
\text { Care }\end{array}$ & $\begin{array}{l}\text { Acute } \\
\text { Care }\end{array}$ & $\begin{array}{c}\text { Home } \\
\text { Care }\end{array}$ & Education \\
\hline Mentor & 80.0 & 90.0 & 60.0 & 66.6 \\
\hline Staff development & 77.3 & 90.0 & 60.0 & 33.3 \\
\hline $\begin{array}{l}\text { Self development: } \\
\text { Formal education } \\
\text { Continuing }\end{array}$ & - & 20.0 & - & 16.7 \\
\hline $\begin{array}{l}\text { education } \\
\text { Program }\end{array}$ & 77.8 & 50.0 & 44.4 & 16.7 \\
\hline $\begin{array}{l}\text { development } \\
\text { Educational }\end{array}$ & 75.0 & 88.9 & 100.0 & 100.0 \\
\hline services & 70.0 & 80.0 & 87.5 & 100.0 \\
\hline Direct teaching & 60.0 & 33.3 & 37.5 & 83.4 \\
\hline Grant writing & - & - & 12.5 & 100.0 \\
\hline
\end{tabular}


According to several executives, having a functioning, productive staff was considered to be the most satisfying part of their role. The idea of ongoing development as a part of productivity emerged especially in the larger hospitals and home care and education settings. Personnel were recognized as a valuable resource worthy of development to meet new and changing organizational needs.

Nurse executives in practice and education settings play a unique role in creating the environment in which professional practice can occur and endure. As Lodge and Pietraschke (1986) note, executives can determine what professional nursing is and how it should be practiced. They hold the keys to maximizing the use of nursing knowledge and to continued growth and development of the staff. This is the essential ingredient of a professional practice environment in any setting.

\section{Summary}

The results of this study support previous findings of a new executive role that demands advanced education in administration and clinical leadership as well as educational skills. The need for advanced education is especially noted in longterm care settings where for the most part executives are not prepared adequately for the leadership responsibilities that they have assumed.

This exploration suggests that the nurse executive plays a strong role of influence, blending teaching and learning expertise in formal and informal patterns. Strong patterns of self-development emerged from the data over and over, sometimes in professional organization memberships and other peer networking, sometimes in continuing education, sometimes in public speaking and most of all in individual homework activities.

Respondents described the need to be updated in financial management, bargaining, reimbursement policies, data management and computer applications. Preparation time for meetings and speaking engagements increased incrementally according to level of responsibility and position at the corporate level. Although one might argue that these activities are all administrative, these data suggest a strong educational tone. The opportunity to influence staff development is apparent in all settings. Executives function as role models and mentors, teachers, and facilitators of personal development. Future studies will undoubtedly question in greater depth the importance of activities identified by a few individuals, for example, consultation and service on advisory committees and review boards since these are emerging as important activities for other executives.

\section{References}

Drucker, P. F. (1980). Managing in turbulent times. New York: Harper \& Row Glaser, B. G., \& Strauss, A. L. (1967). The discovery of grounded theory. Chicago: Aldine Press.

Lodge, M. P., \& Pietraschke, F. (1986). Professional education and practice of nurse administrators/directors of nursing in long-term care (Phase 11). Kansas City: American Nurses' Foundation.

Mintzberg, H. (1973). The nature of managerial work. New York: Harper \& Row.

Poulin, M. A. (1984, February). The nurse executive role: A structural and functional analysis. Journal of Nursing Administration, 14(2), 9-14.

Price, S. A. (1984). Master's programs preparing nursing administrators. Journal of Nursing Administration, 14(1), 11-17.

Simms, L. M. (1981). The grounded theory approach in nursing research. Nursing Research, 30(6), 356-359.

Simms, L. M., Price, S. A., \& Pfoutz, S. K. (1985). Nurse executives: Functions and priorities. Nursing Economics, 3(4), 238-244.

Stevens, B. (1981). The role of the nurse executive. Journal of Nursing Administration, 11(2), 19-23.

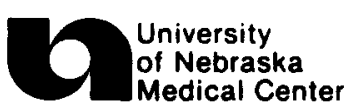

\section{Nursing Department Chairpersons, Faculty}

Chairpersons - Dynamic, progressive leaders sought for three departments: (1) Adult Health \& IIIness; (2) Parent-Child; and (3) Nursing Administration, Education and Science.

Faculty - Four key, tenure-track positions to strengthen graduate specialty offerings and research in critical care of adults; neonatal/pediatric critical care; oncology and gerontology.

College is part of the only state supported university in Nebraska and of an academic health science center that has recognized leadership in liver transplants, bone marrow transplants and cancer research and treatment. Climate supportive of research and scholarly activity. College offers NLN accredited BSN and MSN, participates in Medical Sciences Interdisciplinary Ph.D., and has been qualifying for Biomedical Research Support Grants. Requirements include doctorate in nursing or related area, masters in nursing speciality appropriate to position sought, teaching experience at baccalaureate and graduate level and evidence of research and scholarly productivity. Salary and rank commensurate with position and qualifications. Send curriculum vita and name of three references to Dr. Rosalee Yeaworth, Dean, College of Nursing, University of Nebraska Medical Center, 42nd \& Dewey Avenue, Omaha, NE 68105-1065. AA/EOE

\section{BOOKS REGEIVED}

IMAGE: Journal of Nursing Scholarship thanks the publishers who have kindly supplied the following books. The listing implies neither endorsement nor review.

Cox, Helen C., Harsanyi, Bennie and Dean, Lyn C. Computers and Nursing: Application to Practice, Education and Research, Norwalk, CT: Appleton \& Lange, 1987, \$24.95.

Darovic, Gloria Oblouk, Hemodynamic Monitoring: Invasive and Noninvasive Clinical Application, Philadelphia: W. B. Saunders Company, 1987, $\$ 21.95$.

Drain, Cecil B. and Christoph, Susan Shipley, The Recovery Room: A Critical Care Approach to Post Anesthesia Nursing, Second Edition, Philadelphia: W. B. Saunders Company, 1987, \$39.95.

Durham, Jerry D. and Cohen, Felissa L. (Eds.), The Person with AIDS: Nursing Perspectives, New York: Springer Publishing Company, $1987, \$ 24.95$.

Felton, Geraldene (Ed.), Proceedings of the National Conference on Nursing Practice in Clinical Genetics: Prospects for the 21st Century, Iowa City, Iowa: The University of Iowa College of Nursing, 1986, $\$ 15.00$.

Kamen, Betty and Fraley, Lynn, Nutrition in Nursing: The New Approach, New Canaan, CT: Keats Publishing, 1987, \$14.95.

Miller, Benjamin F. and Keane, Claire Brackman, Encyclopedia and Dictionary of Medicine, Nursing, and Allied Health, Fourth Edition, Philadelphia: W. B. Saunders Company, 1987, $\$ 24.95$ (deluxe edition), $\$ 19.95$ (economy version).

Petillo, M. H. and Mondoux, L. C. A. (Guest Eds.), The Nursing Clinics of North America, Vol. 22, No. 2, Philadelphia: W. B. Saunders Company, 1987, $\$ 39.00$ per year.

Quinn, Carroll A. and Smith, Michael D., The Professional Commitment: Issues and Ethics in Nursing, Philadelphia: W. B. Saunders Company, 1987, $\$ 16.95$.

Thompson, Eleanor Dumont, Pediatric Nursing: An Introductory Text, Fifth Edition, Philadelphia: W. B. Saunders Company, 1987, $\$ 19.95$. 